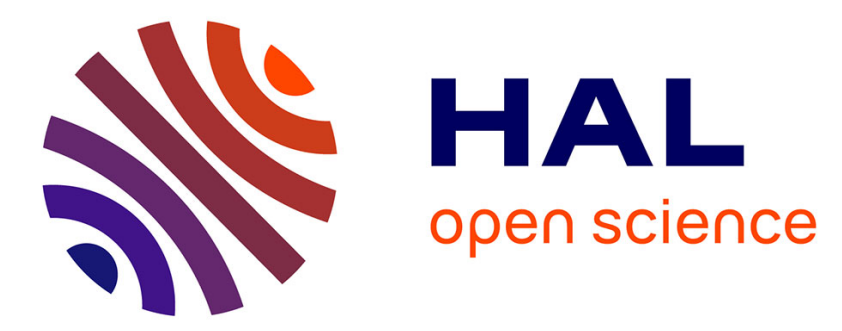

\title{
FSH-stimulated PTEN activity accounts for the lack of FSH mitogenic effect in prepubertal rat Sertoli cells
} Joëlle Dupont, Astrid Musnier, Jérémy Decourtye, Thomas Boulo, Charlotte Lécureuil, Hervé Guillou, Sophie Valet, Sophie Fouchécourt, Jean-Luc Pitetti, Serge Nef, et al.

\section{To cite this version:}

Joëlle Dupont, Astrid Musnier, Jérémy Decourtye, Thomas Boulo, Charlotte Lécureuil, et al.. FSHstimulated PTEN activity accounts for the lack of FSH mitogenic effect in prepubertal rat Sertoli cells. Molecular and Cellular Endocrinology, 2009, 315 (1-2), pp.271. 10.1016/j.mce.2009.09.016 . hal-00547657

\section{HAL Id: hal-00547657 \\ https://hal.science/hal-00547657}

Submitted on 17 Dec 2010

HAL is a multi-disciplinary open access archive for the deposit and dissemination of scientific research documents, whether they are published or not. The documents may come from teaching and research institutions in France or abroad, or from public or private research centers.
L'archive ouverte pluridisciplinaire $\mathbf{H A L}$, est destinée au dépôt et à la diffusion de documents scientifiques de niveau recherche, publiés ou non, émanant des établissements d'enseignement et de recherche français ou étrangers, des laboratoires publics ou privés. 


\section{Accepted Manuscript}

Title: FSH-stimulated PTEN activity accounts for the lack of FSH mitogenic effect in prepubertal rat Sertoli cells

Authors: Joëlle Dupont, Astrid Musnier, Jérémy Decourtye, Thomas Boulo, Charlotte Lécureuil, Hervé Guillou, Sophie Valet, Sophie Fouchécourt, Jean-Luc Pitetti, Serge Nef, Eric

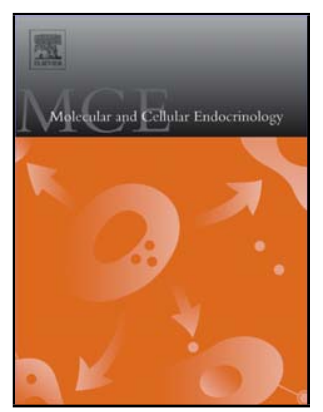
Reiter, Pascale Crépieux

PII: S0303-7207(09)00499-7

DOI: doi:10.1016/j.mce.2009.09.016

Reference: $\quad$ MCE 7328

To appear in: $\quad$ Molecular and Cellular Endocrinology

Received date: 23-7-2009

Revised date: $\quad$ 9-9-2009

Accepted date: $\quad$ 15-9-2009

Please cite this article as: Dupont, J., Musnier, A., Decourtye, J., Boulo, T., Lécureuil, C., Guillou, H., Valet, S., Fouchécourt, S., Pitetti, J.-L., Nef, S., Reiter, E., Crépieux, P., FSH-stimulated PTEN activity accounts for the lack of FSH mitogenic effect in prepubertal rat Sertoli cells, Molecular and Cellular Endocrinology (2008), doi:10.1016/j.mce.2009.09.016

This is a PDF file of an unedited manuscript that has been accepted for publication. As a service to our customers we are providing this early version of the manuscript. The manuscript will undergo copyediting, typesetting, and review of the resulting proof before it is published in its final form. Please note that during the production process errors may be discovered which could affect the content, and all legal disclaimers that apply to the journal pertain. 
Title: FSH-stimulated PTEN activity accounts for the lack of FSH mitogenic effect in prepubertal rat Sertoli cells

Authors: Joëlle Dupont\#, Astrid Musnier\#, Jérémy Decourtye, Thomas Boulo, Charlotte Lécureuil $^{\mathrm{ab}}$, Hervé Guillou ${ }^{\mathrm{ac}}$, Sophie Valet, Sophie Fouchécourt, Jean-Luc Pitetti $^{\mathrm{d}}$, Serge Nef ${ }^{\mathrm{d}}$, Eric Reiter, Pascale Crépieux ${ }^{1}$

Address: BIOS group, INRA, UMR85, Unité Physiologie de la Reproduction et des Comportements, F-37380 Nouzilly, France ; CNRS, UMR6175, F-37380 Nouzilly, France ; Université François Rabelais, F-37041 Tours, France, ${ }^{a}$ The Inositide Laboratory, The Babraham Institute, Cambridge, CB2 4AT , United Kingdom. ${ }^{\mathrm{d}}$ Department of Genetic Medicine and Development, University of Geneva Medical School, University of Geneva, 1211 Geneva 4, Switzerland.

Present address: ${ }^{\mathrm{b}}$ LDRG, INSERM U967 / CEA / Université Paris 7, 18 Route du Panorama 92265 Fontenay-aux-Roses, France, and ${ }^{\mathrm{c}}$ Laboratoire de Pharmacologie et Toxicologie, INRA, «Pharmacologie Moléculaire», 180 Chemin de Tournefeuille, 31931 Toulouse, France

\# Equal contribution

\footnotetext{
${ }^{1}$ Corresponding author : Pascale Crépieux, BIOS group, INRA, UMR85, Unité Physiologie de la Reproduction et des Comportements, F-37380 Nouzilly, France ; CNRS, UMR6175, F-37380 Nouzilly, France ; Université François Rabelais, F-37041 Tours, France. Phone : 332474275 14, Fax : 332474277 43, E-mail : Pascale.Crepieux@tours.inra.fr
} 
Keywords: FSH, PTEN, cell differentiation (rat testis), (Sertoli cells)

\begin{abstract}
Follicle-stimulating hormone (FSH) controls the proliferation and differentiation of Sertoli cells of the testis. FSH binds a G protein-coupled receptor (GPCR) to stimulate downstream effectors of the phosphoinositide-3 kinase (PI3K)-dependent pathway, without enhancing PI3K activity. To clarify this paradox, we explored the activity of phosphatase and tensin homolog deleted in chromosome 10 (PTEN), the PI3K major regulator, in primary cultures of rat Sertoli cells. We show that, within minutes, FSH increases PTEN neosynthesis, requiring the proteasomal degradation of an unidentified intermediate, as well as PTEN enzymatic activity. Importantly, introducing an antisense cDNA of PTEN into differentiating Sertoli cells restores FSHdependent cell proliferation. In conclusion, these results provide a new mechanism of PTEN regulation, which could serve to block entry into S phase of Sertoli cells, while they are proceeding through differentiation in pre-pubertal animals.
\end{abstract}




\section{INTRODUCTION}

$\mathrm{G}$ protein-coupled receptors represent the largest class of cell surface receptors, involved in most physiological regulations, including reproduction. Once activated by their cognate ligand, they mediate diverse intracellular signalling events, mainly transduced by their interaction with heterotrimeric $G$ proteins, and with their companion scaffolding proteins, $\beta$-arrestins (Reiter and Lefkowitz, 2006). Among those signalling events, some GPCRs stimulate the activity of class IB phosphatidylinositol-3 kinase (Stephens et al., 1993), which converts phosphoinositide(4, 5)P2 (PIP2) to phosphoinositide(3, 4, 5)P3 (PIP3) in the lipid bilayer. PIP3 then serves as a second messenger which recruits signalling proteins containing a pleckstrin homology domain (Klarlund et al., 1997).

The biological activity of class I PI3K is antagonized by a key regulator of phosphoinositide steady-state, PTEN, which dephosphorylates PIP3 in position 3 (Vazquez and Devreotes, 2006). As such, PTEN has been largely acknowledged as a tumor suppressor, inactivated by loss of heterozygosity on chromosome 10q23, by mutation or by promoter methylation silencing (Carnero et al., 2008). While those properties of PTEN have been widely documented, relatively little is known about PTEN regulation. Pten gene transcription has been shown to be up-regulated through DNA binding sequences for early growth regulated transcription factor 1 (EGR1) (Virolle et al., 2001) for example, and down-regulated through mitogen-activation

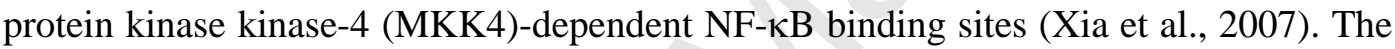
PTEN protein is stabilized by direct interaction with casein kinase II that limits its caspase-mediated degradation (Torres et al., 2003). PTEN is also regulated by posttranslational modifications, such as mono/polyubiquitination, phosphorylation, acetylation or oxidation, which control its activity, stability or sub-cellular localization (Tamguney and Stokoe, 2007).

The FSH-R is a GPCR mainly expressed at the cell surface of Sertoli cells of the seminiferous tubules, where it transduces activation of diverse signalling pathways, which greatly vary according to the differentiation stage, leading to appropriate cellular responses (Crépieux et al., 2001; Lecureuil et al., 2007; Meroni et al., 2002; Meroni et al., 2004). For example, 5 day-old rats Sertoli cells proliferate in response to FSH. At this stage, FSH enhances the phosphorylation of MAP kinases ERK1 and ERK2, thus increasing cyclin D1 expression. In contrast, FSH totally switches off the ERK pathway in 19 day-old rat differentiating Sertoli cells, and in vitro, cell proliferation becomes insensitive to FSH (Crépieux et al., 2001). Likewise, we observed that the signaling pathways activated by FSH upstream of the p70 S6 kinase (p70S6K1) are different at each of those developmental stages, resulting in differential phosphorylation patterns of the enzyme (Lécureuil et al., 2005) (Musnier et al., submitted). In particular, in differentiating Sertoli cells, FSH stimulates downstream targets of PI3K, such as mammalian Target Of Rapamycin (mTOR). However, we provided evidence for a tonic PI3K activation in these cells (Lécureuil et al., 2005). To gain a better insight onto PI3K regulation in differentiating Sertoli cells, here we analyzed expression, activity, and functionality of PTEN, the key regulator of PI3K biological function. 


\section{MATERIALS AND METHODS}

\section{Purification of Sertoli cells}

Animals were treated following the current ethical guidelines of the European Community. Sertoli cells were isolated from testes of 5 or 19 day-old Wistar rat, as published (Guillou et al., 1986), and fifty thousand cells $/ \mathrm{cm}^{2}$ were plated on CellBind plates (Corning) in Dulbecco's minimum essential medium (DMEM) supplemented with penicillin (100 IU/ ml), streptomycin $(100 \mu \mathrm{g} / \mathrm{ml})$, glutamine $(2 \mathrm{mM})$, retinol (50 $\mathrm{ng} / \mathrm{ml})$, vitamin $\mathrm{E}(200 \mathrm{ng} / \mathrm{ml})$ and human transferrin $(5 \mu \mathrm{g} / \mathrm{ml})$. The medium was replaced after 24 hours to remove unattached cells, and Sertoli cells were stimulated by $100 \mathrm{ng} / \mathrm{ml}$ porcine FSH (bioactivity of 160 x NIH-FSH-P1) purified by Dr J. Closset Université de Liège, Belgium (Closset and Hennen, 1989), or by $10 \mathrm{ng} / \mathrm{ml}$ tumournecrosis factor $\alpha(\mathrm{TNF} \alpha)$. MG132 and lactacystin were from Calbiochem (Merck Chemical Ltd). All other reagents were from Sigma Chemical Co (St-Louis, MO).

\section{Cell transfections and plasmids}

Once purified from testes, Sertoli cells were seeded at a density of 3, 750 cells / $\mathrm{mm}^{2}$ in 24-well CellBind plates. On the next day, the JetPEI reagent from Polyplus was used, to transfect cells in each well with $100 \mathrm{ng}$ of E2F1-luciferase reporter plasmid, 25 ng of Renilla luciferase plasmid, and 900 ng of pBK-CMV plasmid or pBK-CMV plasmid encoding antisense PTEN. Forty-eight hours after transfection, cells were stimulated with FSH for 8 hours, and then were lysed in $100 \mu \mathrm{l} /$ well of passive lysis buffer, according to the manufacturer's instructions (Dual luciferase kit, Promega). Cell lysates were then transferred to blind 96-well plates and the chemiluminescense produced by the firefly and renilla luciferases was detected on an Ascent luminoscan (Thermo Labsystems). The E2F1-driven luciferase plasmid (E2F1-luc) contains 3 E2F1- and one Sp1-binding sites linked to the thymidine kinase promoter, and was donated by Dr A. Harel-Bellan (Villejuif, France). The mammalian expression vector pBK-CMV, driven by the cytomegalovirus immediate-early promoter and containing the neomycin resistance gene, was purchased from Stratagene Cloning Systems (La Jolla, CA). The PTEN cDNA (1218 pb, a gift from Dr. Kaz Matsumoto, NIDCR, NIH, Bethesda, MD) was subcloned into the EcoRI and XbaI sites of PBK-CMV in the antisense orientation, as described in (Wu et al., 2004). The orientation of the construct was verified by PCR and DNA sequencing. The plasmid encoding Renilla luciferase was provided in the Dual luciferase kit.

\section{Western blot analysis}

Sertoli cells were lysed in TNET lysis buffer (20 mM Tris pH 7.8, $50 \mathrm{mM} \mathrm{NaCl}$, $5 \mathrm{mM}$ EGTA, $1 \% \mathrm{vol} / \mathrm{vol}$ Triton X-100, $1 \mathrm{mM}$ phenylmethylsulfonyl fluoride, $4 \mathrm{mM}$ $\mathrm{Na}_{3} \mathrm{VO}_{4}, 5 \mu \mathrm{g} / \mathrm{ml}$ leupeptin, $5 \mu \mathrm{g} / \mathrm{ml}$ pepstatin, and $5 \mu \mathrm{g} / \mathrm{ml}$ aprotinin, and $40 \mu \mathrm{g}$ of proteins were separated by SDS-PAGE and transferred to nitrocellulose membrane (Whatman, Dassel, Germany). Membranes were saturated with TBST-BSA (Tris Buffer Saline with $0.1 \%$ Tween 20, 3 \% Bovine Serum Albumin) and were probed with the following antibodies, all diluted 1: 1000 in Tris Buffer Saline / $0.1 \%$ Tween 20 (TBS/T) with $3 \%$ BSA: rabbit anti-phospho-IкB $\alpha$, anti-PTEN (Cell Signalling Technology), anti-phospho-Akt [Ser473] (Abcam), anti-rabbit secondary antibody (Eurobio). Membranes were also probed with anti-vinculin or anti-actin (Sigma Aldrich) antibodies to monitor gel loading. Western blots were revealed with enhanced 
chemiluminescence (NEN Life Science Products). Films were scanned and the optical density of the signals was measured with ImageMaster 1D Elite version 4 software (Amersham Biosciences).

\section{In vitro PTEN enzymatic activity}

After stimulation, Sertoli cells were disrupted on ice for $30 \mathrm{~min}$ in lysis buffer (137 mM NaCl, $20 \mathrm{mM}$ Tris $\mathrm{HCl} \mathrm{pH}$ 7.5, $1 \mathrm{mM} \mathrm{MgCl}$, $1 \mathrm{mM} \mathrm{CaCl} 2,150 \mathrm{mM} \mathrm{Na} \mathrm{VO}_{4}$, $1 \%$ Nonidet P-40, 10 \% glycerol, 2 mM phenylmethylsulfonyl fluoride (PMSF), 10 $\mu \mathrm{g} / \mathrm{ml}$ aprotinine). Briefly, Sertoli cell extracts were immunoprecipitated with antiPTEN antibody. PTEN phosphatase activity correlates with the amount of phosphate released from $\mathrm{diC}_{8}-\mathrm{PIP}_{3}$, visualized by a colorimetric assay (Biomol Green ${ }^{\mathrm{TM}}$ reagents) read at $620 \mathrm{~nm}$.

\section{Rat transferrin quantification}

Secreted transferrin was measured in $100 \mu \mathrm{l}$ of Sertoli cell culture media by radioimmunoassay, as described (Suire et al., 1997). All standards and samples were assayed in triplicate.

\section{PIP3 assay by protein-lipid overlay}

To estimate PI3K activity, PIP3 was quantified from $10^{7}$ Sertoli cells as described recently (Guillou et al., 2007). Briefly, PtdIns-rich fractions were extracted with chloroform/ methanol, selectively isolated on neomycin beads, eluted with methanol-choloroform-HCl. Purified PtdIns were spotted onto a nitrocellulose membrane, blotted overnight at $4^{\circ} \mathrm{C}$ with the $\mathrm{PH}$ domain of the General Receptor for Phosphoinositide 1 (GRP1) fused to green fluorescent protein (GFP). Membranes were then probed with a rabbit anti-GFP polyclonal antibody coupled to HRP, the chemiluminescence was detected with the ECL reagent (Amersham) and acquired with the Image Reader LAS-1000 charge-coupled device (CCD) camera (Fujifilm). Densitometry was measured with the AIDA software with local background subtraction.

\section{Sertoli cell metabolic labeling}

Twenty million Sertoli cells were pre-incubated with actinomycin D (5 $\mu \mathrm{g} / \mathrm{ml})$, then labelled with $200 \mu \mathrm{Ci}(0.1 \mathrm{nmole})$ of ${ }^{35} \mathrm{~S}-\mathrm{Met} /{ }^{35} \mathrm{~S}$-Cys, stimulated by $100 \mathrm{ng} / \mathrm{ml}$ FSH for one hour, and lysed in $300 \mu$ RIPA buffer $(150 \mathrm{mM} \mathrm{NaCl}, 50 \mathrm{mM}$ Tris pH 8.0, mM EDTA, $1 \%$ Triton X-100). PTEN was immunoprecipitated in the cell lysates with rabbit anti-PTEN antibody (1: 100), overnight at $4^{\circ} \mathrm{C}$, and. the immunoprecipitates were analyzed by SDS-PAGE. Then the gel was vacuum-dried and exposed to a phosphorImager screen.

\section{RNA extraction and Q-RT-PCR}

Total RNA were extracted from $3 \times 10^{6}$ cells per condition, by using the RNABle reagent (Eurobio, les Ulis, France), according to the manufacturer's instructions. For each time point, three independent sets of total RNA from FSHstimulated cells were isolated and used as a template for probe generation. RNA integrity and quantity was assessed using RNA 6000 nanochips with an Agilent 2100 bioanalyser (Agilent Technologies, Inc., Palo Alto, CA). One $\mu \mathrm{g}$ of total RNAs was reverse transcribed with the Superscript II Reverse Transcriptase from Invitrogen (Life Technologies, Gaithersburg, MD, USA) according to the manufacturer's instructions, 
and 1/40th of the cDNA was used as template for PCR amplification as previously described (Cederroth et al., 2007). A mean quantity was calculated from triplicate PCR reactions for each sample, and this quantity was normalized to two similarly measured quantities of normalization genes (GAPDH, rps29 and tubb). The statistical significance of fold-changes was determined by a paired Student's $t$-test. Rat PTEN primers used for qRT-PCR are:

forward 5’ AATGTTCAGTGGCGGAACTTG 3’ and reverse 5’ TCCTGAGTTGGAGGAGTAGATCTTC 3’.

Softwares

The Cell Designer graphic interface (http://celldesigner.org) has used to describe the signalling pathways explored herein.

\section{Data analysis}

Measurements were performed in duplicates or triplicates and the mean values \pm s.e.m of at least 3 independent experiments are presented. Results were generally expressed as percent of the maximum values. Statistical analysis of the data was performed using one-way ANOVA (Bonferroni's multiple comparison tests) to compare samples (GraphPad PRISM Software, San Diego, CA). Values with $\mathrm{p}<0.05$ were considered as significantly different. 


\section{RESULTS}

\section{Phosphoinositide level in Sertoli cells}

To estimate PI3K activity, we analyzed the PIP3 content of rat Sertoli cells by protein-lipid overlay (Guillou et al., 2007) and expressed the results as \% of the response to insulin, taken as a positive control. As expected from our previous report (Lécureuil et al., 2005), in differentiating Sertoli cells isolated from prepubertal 19-day old rats, the level of PIP3 was basally elevated, when compared to the level of PIP3 measured in proliferating Sertoli cells from 5-day old rat neonates (Figure 1A). Furthermore, in differentiating Sertoli cells, the PIP3 level was not significantly increased upon FSH stimulation (Figure 1B) nor by Insulin stimulation (data not shown). Accordingly, phosphorylation of the Akt Ser/Thr kinase on Ser473 was not significantly enhanced upon FSH stimulation, whereas it was clearly increased by Insulin stimulation for $60 \mathrm{~min}$, as expected (Figure 1C). Neither was phosphorylation of Akt Thr308 visible in FSH-stimulated cells (data not shown). Accordingly, phosphorylation of the PtdIns-dependent transcription factor Foxo1 was not enhanced upon FSH stimulation of these cells (Musnier et al., 2009).

\section{FSH enhances PTEN protein level and activity}

Since the PIP3 level was basally high in differentiating Sertoli cells, we anticipated that the expression of PTEN could be basally low. This was actually the case, but surprisingly, time-course stimulations led to a gradual increase in PTEN protein, as soon as 15 min of FSH stimulation (Figures 2A, 2B). This increase peaked around 60 min and remained high thereafter. It required the continuous presence of the hormone in the cell medium, since when the FSH-containing medium was replaced by fresh medium for the last 120 minutes of incubation, PTEN protein expression returned close to its basal level (Figure 2C). Importantly, PTEN activity paralleled PTEN upregulation in response to FSH (Figure 2D), unless the hormone was withdrawn for the last 120 minutes as above (Figure 2E). Insulin stimulation also led to an increase in PTEN activity (Figure 2F). Therefore, enhanced PTEN activity by FSH could counterbalance PI3K activity by maintaining a constant level of PIP3, as shown in Figure 1B.

\section{FSH enhances PTEN neo-synthesis}

As expected from such an early cellular process, preventing transcription with actinomycin D did not significantly impair FSH-induced PTEN up-regulation (Figure 3A), suggesting that FSH enhanced PTEN expression by a post-transcriptional mechanism. The efficacy of actinomycin D was assessed by quantifying extracellular transferrin, whose gene has been reported to be regulated by FSH mainly transcriptionally (Suire et al., 1995) (Figure 3B). To conclusively support a posttranscriptional regulation of PTEN, we assessed by quantitative real time RT-PCR the expression levels of PTEN upon gradual increase of FSH stimulation. We found that PTEN transcripts decreased over time (Figure 3C), thus ruling out the possibility that the accumulation of PTEN proteins could be due to an up-regulation of PTEN transcription. Therefore, one possibility was that FSH would enhance PTEN proteosynthesis. When newly synthesized PTEN was labelled with ${ }^{35} \mathrm{~S}-\mathrm{Met} /{ }^{35} \mathrm{~S}$-Cys, we observed that FSH was able to increase PTEN protein level (160\% when normalized with a non-specific band), even when transcription was blocked (Figure 3D). 


\section{PTEN up-regulation requires FSH-induced proteolysis}

We next sought to explore the mechanism whereby PTEN protein level was enhanced by FSH. Since PTEN degradation has been shown in other systems to be mediated by the proteasome (Torres and Pulido, 2001), we tested whether FSH would inhibit a constitutive proteasome-mediated degradation of PTEN, in addition to increasing PTEN proteosynthesis. In time-course experiments, the MG 132 proteasome inhibitor hampered FSH-induced PTEN up-regulation (Figure 4A, 4B). Efficacy and specificity of MG 132 were further confirmed by stabilization of the I $\mathrm{BB} \alpha$ protein (Figure 4C) in TNF $\alpha$-treated cells (Traenckner et al., 1994). Similar results were obtained with an unrelated proteasome inhibitor, lactacystin (Figure 4D), indicating that proteolysis of an inhibitory protein was a prerequisite to PTEN upregulation by FSH.

\section{PTEN depletion restores FSH mitogenic effect in Sertoli cell from prepubertal rats}

Owing to its well-known biological function as a tumor suppressor, PTEN could be involved in triggering Sertoli cells in prepubertal animals towards their differentiation program, by limiting their mitogenic ability. To address this question, a pBK-CMV plasmid encoding antisense PTEN or wild-type pBK-CMV plasmid was introduced in differentiating Sertoli cells, together with a reporter plasmid encoding the luciferase cDNA under the control of E2F1-responsive elements. E2F1 binding sites can be used as sensors of the G1/S transition of the cell cycle. In Sertoli cells transfected with the pBK-CMV empty vector, FSH could not enhance luciferase activity (Figure 5A), consistently with previous data indicating that FSH does not enhance proliferation of Sertoli cells isolated from prepuberal rats (Crépieux et al., 2001; Orth, 1982). In contrast, in FSH-stimulated cells transfected with antisense PTEN, luciferase activity was significantly enhanced, suggesting that Sertoli cells have gained sensitivity to FSH to undergo proliferation. Therefore, upregulation of PTEN could serve to limit Sertoli cell proliferation when undergoing differentiation. In line with this view, FSH stimulation could not enhance PTEN expression in Sertoli cells isolated from neonates (Figure 5B).

\section{DISCUSSION}

In this paper, we have identified a novel regulation of PTEN by FSH. It is shown here that FSH enhances the protein level of the PI3K regulator PTEN, within minutes, while PI3K activity remains apparently constant, as seen by the absence of Akt phosphorylation. We propose that FSH-induced PI3K activity could not be observed precisely because PTEN expression is upregulated by FSH stimulation at the same time. In contrast, insulin enhances PTEN activity, probably as a negative feedback mechanism, as previously reported (Lackey et al., 2007; Moorehead et al., 2003). Hence, we favour a different mechanism for PTEN activation by insulin since insulin, unlike FSH, activates Akt in our cell model.

FSH-induced upregulation of PTEN was due to an enhanced PTEN neosynthesis rate. We postulate that in the absence of hormone, an undefined inhibitor $\mathrm{X}$ degrades or keeps PTEN from accumulating, which explains that PI3K activity is constitutively elevated. Obviously, this does not imply that the effect is direct, and this inhibitor could destabilize the PTEN protein or mRNA, although a direct input on the translational machinery cannot be ruled out. FSH stimulation would then target this inhibitor to the 
proteasome for degradation, ultimately leading to PTEN accumulation and subsequent conversion of PIP3 to PIP2, as shown here.

What could be the physiological role of an FSH- induced rapid stimulation of PTEN in Sertoli cells? Sertoli cells isolated from 19 day-old rats were analyzed in this study. At this developmental stage, cells are proceeding through their differentiation program, and the mitosis rate slows down and becomes insensitive to FSH (Crépieux et al., 2001; Orth, 1982). Since PTEN level is not altered by FSH exposure of proliferating Sertoli cells recovered from neonate rats, it was likely that FSH-stimulated PTEN expression could be linked to Sertoli cell terminal differentiation. Clearly, this view is supported by the data presented herein, since the introduction of a plasmid encoding antisense PTEN in differentiating Sertoli cells knocks-down the endogenous PTEN mRNA and restores the responsiveness of these cells to FSH to undergo proliferation. This is consistent with the well admitted role of PTEN as a negative regulator of cell proliferation and parallels the previously proposed role of PTEN in the transition from proliferation to differentiation of granulosa cells, within the ovarian follicle (Froment et al., 2005).

So far, we have never been able to visualize phosphorylation of Akt, an indirect target of PI3K activity, before two hours of FSH stimulation (our unpublished results). Our results contradict those previously published which show that FSH enhances Akt phosphorylation in Sertoli cells from 20 day-old rats (Meroni et al., 2004). Differences in cell culture conditions could be amenable for this discrepancy, which otherwise remains obscure. However, it is clearly reminiscent of the observation that TSH, a glycoprotein hormone structurally related to FSH, stimulates p70S6K1 in a PI3K-dependent manner, without activating Akt (Suh et al., 2003). Furthermore, the muscarinic M3 receptor mediates p70S6K1 activation and enhances its phosphorylation on the T389 residue through an mTOR-dependent mechanism, in an astrocytoma cell line. Only a permissive, low level of PI3K activity is required (Tang et al., 2003) similarly to our observations in differentiating Sertoli cells stimulated by FSH (Lécureuil et al., 2005). While Akt is not activated in astrocytoma cells when stimulated by the M3 cognate agonist carbachol, PDK1 could be the permissive signal. Noteworthy, GPCRs have developed strategies of their own to attenuate PI3K signalling, by virtue of their ability to recruit the adapter proteins $\beta$-arrestins. For example, in response to the ligand-activated PAR2, PI3K is sequestered from the lipid components of the plasma membrane by $\beta$-arrestins (Wang and DeFea, 2006). Whether this is also the case in Sertoli cells stimulated with FSH remains to be investigated, since, the FSH-bound receptor also recruits $\beta$-arrestins to regulate its desensitization (Nakamura et al., 1998; Troispoux et al., 1999) and cell signalling (Kara et al., 2006).

In conclusion, in primary cultures of Sertoli cells from prepubertal rats, in which the molar ratio of the signalling components are balanced, we have identified a novel regulation of tumor suppressor PTEN by FSH. This mechanism appears to be critically involved in the loss of mitogenic potential of Sertoli cells, leading to their terminal differentiation. 


\section{ACKNOWLEDGEMENTS}

The authors are indebted to Dr Alfredo Ulloa-Aguirre (Instituto Mexicano del Seguro Social, Mexico) for critical reading of the manuscript, Dr Corinne Abbadie (Pasteur Institute, Lille, France) for the IкB $\alpha$ control, to the rat breeders Claude Cahier and Jean-Claude Braguer, to Drs Len Stephens and Phil Hawkins for the PIP3 quantification (Babraham Institute, Cambridge, UK). A.M. was funded by a fellowship from the Region Centre and from the Institut National de la Recherche Agronomique (INRA), C.L. was granted by the Fondation pour la Recherche Médicale, and H.G. was a BBSRC fellow. This work was supported by the INRA, by the Centre National de la Recherche Scientifique and by Université de Tours. 


\section{REFERENCES}

Carnero, A., Blanco-Aparicio, C., Renner, O., Link, W. Leal, J.F., 2008. The PTEN/PI3K/AKT signalling pathway in cancer, therapeutic implications. Curr Cancer Drug Targets 8, 187-98.

Cederroth, C.R., Schaad, O., Descombes, P., Chambon, P., Vassalli, J.D. Nef, S., 2007. Estrogen receptor alpha is a major contributor to estrogen-mediated fetal testis dysgenesis and cryptorchidism. Endocrinology 148, 5507-19.

Closset, J. Hennen, G., 1989. Biopotency of highly purified porcine FSH and human LH on gonadal function. J Endocrinol 120, 89-96.

Crépieux, P., Marion, S., Martinat, N., Fafeur, V., Vern, Y.L., Kerboeuf, D., Guillou, F. Reiter, E., 2001. The ERK-dependent signalling is stage-specifically modulated by FSH, during primary Sertoli cell maturation. Oncogene 20, 4696709.

Froment, P., Bontoux, M., Pisselet, C., Monget, P. Dupont, J., 2005. PTEN expression in ovine granulosa cells increases during terminal follicular growth. FEBS Lett 579, 2376-82.

Guillou, F., Martinat, N. Combarnous, Y., 1986. Study of the superactivity of equine follicle-stimulating hormone in in vitro stimulation of rat Sertoli cells. Biochemical and Biophysical Acta 887, 196-203.

Guillou, H., Lecureuil, C., Anderson, K.E., Suire, S., Ferguson, G.J., Ellson, C.D., Gray, A., Divecha, N., Hawkins, P.T. Stephens, L.R., 2007. Use of the GRP1 PH domain as a tool to measure the relative levels of PtdIns(3,4,5)P3 through a protein-lipid overlay approach. J Lipid Res 48, 726-32.

Kara, E., Crepieux, P., Gauthier, C., Martinat, N., Piketty, V., Guillou, F. Reiter, E., 2006. A phosphorylation cluster of five serine and threonine residues in the C-terminus of the follicle-stimulating hormone receptor is important for desensitization but not for beta-arrestin-mediated ERK activation. Mol Endocrinol 20, 3014-26.

Klarlund, J.K., Guilherme, A., Holik, J.J., Virbasius, J.V., Chawla, A. Czech, M.P., 1997. Signaling by phosphoinositide-3,4,5-trisphosphate through proteins containing pleckstrin and Sec7 homology domains. Science 275, 1927-30.

Lackey, J., Barnett, J., Davidson, L., Batty, I.H., Leslie, N.R. Downes, C.P., 2007. Loss of PTEN selectively desensitizes upstream IGF1 and insulin signaling. Oncogene 26, 7132-42.

Lecureuil, C., Kara, E., Guillou, F., Monniaux, D. Crepieux, P., 2007. [Does FSH signaling have a gender?]. Med Sci (Paris) 23, 75-80.

Lécureuil, C., Tesseraud, S., Kara, E., Martinat, N., Sow, A., Fontaine, I., Gauthier, C., Reiter, E., Guillou, F. Crépieux, P., 2005. Follicle-stimulating hormone activates p70 ribosomal protein S6 kinase by protein kinase Amediated dephosphorylation of Thr 421/Ser 424 in primary Sertoli cells. Mol Endocrinol 19, 1812-20.

Meroni, S.B., Riera, M.F., Pellizzari, E.H. Cigorraga, S.B., 2002. Regulation of rat Sertoli cell function by FSH: possible role of phosphatidylinositol 3kinase/protein kinase B pathway. J Endocrinol 174, 195-204.

Meroni, S.B., Riera, M.F., Pellizzari, E.H., Galardo, M.N. Cigorraga, S.B., 2004. FSH activates phosphatidylinositol 3-kinase/protein kinase B signaling pathway in 20-day-old Sertoli cells independently of IGF-I. J Endocrinol 180, 257-65. 
Moorehead, R.A., Hojilla, C.V., De Belle, I., Wood, G.A., Fata, J.E., Adamson, E.D., Watson, K.L., Edwards, D.R. Khokha, R., 2003. Insulin-like growth factor-II regulates PTEN expression in the mammary gland. J Biol Chem 278, 50422-7.

Musnier, A., Heitzler, D., Boulo, T., Tesseraud, S., Durand G, Lécureuil, C., Guillou, H., Poupon, A., Reiter, E. Crépieux, P., 2009. Developmental regulation of p70 S6 kinase by a $G$ protein-coupled receptor dynamically modelized in primary cells. Cellular and Molecular Life Sciences in press.

Nakamura, K., Krupnick, J.G., Benovic, J.L. Ascoli, M., 1998. Signaling and phosphorylation-impaired mutants of the rat follitropin receptor reveal an activation- and phosphorylation-independent but arrestin-dependent pathway for internalization. J Biol Chem 273, 24346-54.

Orth, J.M., 1982. Proliferation of Sertoli cells in fetal and postnatal rats : a quantitative autoradiographic study. Anat Rec 203, 485-492.

Reiter, E. Lefkowitz, R.J., 2006. GRKs and beta-arrestins: roles in receptor silencing, trafficking and signaling. Trends Endocrinol Metab 17, 159-65.

Stephens, L., Eguinoa, A., Corey, S., Jackson, T. Hawkins, P.T., 1993. Receptor stimulated accumulation of phosphatidylinositol $(3,4,5)$-trisphosphate by Gprotein mediated pathways in human myeloid derived cells. EMBO J 12, 226573.

Suh, J.M., Song, J.H., Kim, D.W., Kim, H., Chung, H.K., Hwang, J.H., Kim, J.M., Hwang, E.S., Chung, J., Han, J.H., Cho, B.Y., Ro, H.K. Shong, M., 2003. Regulation of the phosphatidylinositol 3-kinase, Akt/protein kinase B, FRAP/mammalian target of rapamycin, and ribosomal S6 kinase 1 signaling pathways by thyroid-stimulating hormone (TSH) and stimulating type TSH receptor antibodies in the thyroid gland. J Biol Chem 278, 21960-71.

Suire, S., Fontaine, I. Guillou, F., 1995. Follicle stimulating hormone (FSH) stimulates transferrin gene transcription in rat Sertoli cells: cis and trans-acting elements involved in FSH action via cyclic adenosine 3',5'-monophosphate on the transferrin gene. Mol Endocrinol 9, 756-66.

Suire, S., Fontaine, I. Guillou, F., 1997. Transferrin gene expression and secretion in rat sertoli cells. Mol Reprod Dev 48, 168-75.

Tamguney, T. Stokoe, D., 2007. New insights into PTEN. J Cell Sci 120, 40719.

Tang, X., Wang, L., Proud, C.G. Downes, C.P., 2003. Muscarinic receptormediated activation of p70 S6 kinase 1 (S6K1) in 1321N1 astrocytoma cells: permissive role of phosphoinositide 3-kinase. Biochem J 374, 137-43.

Torres, J. Pulido, R., 2001. The tumor suppressor PTEN is phosphorylated by the protein kinase CK2 at its $\mathrm{C}$ terminus. Implications for PTEN stability to proteasome-mediated degradation. J Biol Chem 276, 993-8.

Torres, J., Rodriguez, J., Myers, M.P., Valiente, M., Graves, J.D., Tonks, N.K. Pulido, R., 2003. Phosphorylation-regulated cleavage of the tumor suppressor PTEN by caspase-3: implications for the control of protein stability and PTENprotein interactions. J Biol Chem 278, 30652-60.

Traenckner, E.B., Wilk, S. Baeuerle, P.A., 1994. A proteasome inhibitor prevents activation of NF-kappa B and stabilizes a newly phosphorylated form of I kappa B-alpha that is still bound to NF-kappa B. EMBO J 13, 5433-41. 
Troispoux, C., Guillou, F., Elalouf, J.M., Firsov, D., Iacovelli, L., De Blasi, A., Combarnous, Y. Reiter, E., 1999. Involvement of G-protein coupled receptor kinases and arrestins in desensitization to FSH action. Molecular Endocrinology 9, 1599-1614.

Vazquez, F. Devreotes, P., 2006. Regulation of PTEN function as a PIP3 gatekeeper through membrane interaction. Cell Cycle 5, 1523-7.

Virolle, T., Adamson, E.D., Baron, V., Birle, D., Mercola, D., Mustelin, T. de Belle, I., 2001. The Egr-1 transcription factor directly activates PTEN during irradiation-induced signalling. Nat Cell Biol 3, 1124-8.

Wang, P. DeFea, K.A., 2006. Protease-activated receptor-2 simultaneously directs beta-arrestin-1-dependent inhibition and Galphaq-dependent activation of phosphatidylinositol 3-kinase. Biochemistry 45, 9374-85.

Wu, Y., Karas, M., Dupont, J., Zhao, H., Toyoshima, Y. Le Roith, D., 2004. Multiple signaling pathways are involved in the regulation of IGF-I receptor inhibition of PTEN-enhanced apoptosis. Growth Horm IGF Res 14, 52-8.

Xia, D., Srinivas, H., Ahn, Y.H., Sethi, G., Sheng, X., Yung, W.K., Xia, Q., Chiao, P.J., Kim, H., Brown, P.H., Wistuba, II, Aggarwal, B.B. Kurie, J.M., 2007. Mitogen-activated protein kinase kinase-4 promotes cell survival by decreasing PTEN expression through an NF kappa B-dependent pathway. J Biol Chem 282, 3507-19. 


\section{FIGURE LEGENDS}

Figure 1: PI3K activity in rat Sertoli cells. A. Basal PIP3 content in $10^{7}$ Sertoli cells isolated from 5- and 19-day old rats. B. PIP3 production in 19 day old rat Sertoli cells stimulated with FSH (100 ng/ml) for $60 \mathrm{~min}$. C = unstimulated cell control. Results are expressed as mean \% of the PIP3 response to insulin +/- SEM, in 4 independent overlays, each performed in triplicates. C. Representative Western blot of Akt phosphorylated on Ser473 as a function of FSH stimulation time ( $\mathrm{n}=3$ independent experiments). An actin probe was used to monitor gel loading. Shared superscripts indicate no significant difference, while different superscripts indicate significant differences, at the $\mathrm{P}<0.05$ level.

Figure 2: PTEN expression and activity is rapidly enhanced by FSH signalling in differentiating Sertoli cells.

Time-course stimulation of Sertoli cells isolated from 19-day old rats by FSH (100 ng/ $\mathrm{ml})$. A. Representative Western blot of a time-course of FSH-induced PTEN expression. An actin probe was used to monitor gel loading. B. Quantification of the PTEN signal normalized with the actin signal, in 3 independent experiments. Results are expressed as $\%$ of the maximum PTEN induction +/- SEM C. and E. After $120 \mathrm{~min}$, cells were maintained in the presence of FSH, or the hormone was withdrawn (chase). D and E. PTEN activity in response to FSH. A representative experiment $(n=3)$, with each sample assayed in triplicate, is shown. Crude values in nmoles of phosphate released have been normalized to the \% of PTEN activity in response to insulin, taken as a positive control. F. PTEN activity in response to insulin. A representative experiment (n $=3$ ), with each sample assayed in triplicate, is shown. Results are expressed as nmoles of phosphate released. Shared superscripts indicate no significant difference, while different superscripts indicate significant differences, at the $\mathrm{P}<0.05$ level.

Figure 3: FSH increases PTEN neosynthesis in differentiating Sertoli cells. A. Representative Western blot of FSH-induced PTEN expression in the presence of Actinomycin D $(5 \mu \mathrm{g} / \mathrm{ml})$ ( $\mathrm{n}=3$ independent experiments). An actin probe was used to monitor gel loading. B. Radioimmunoassay of transferrin secreted in the culture medium to monitor the efficiency of Actinomycin D, in Sertoli cells stimulated for 24 hours with FSH. C = unstimulated cell control. C. Detection of PTEN messenger RNA expression levels by real-time RT-PCR, in Sertoli cells stimulated with FSH for the indicated period of time. Results are expressed as mean \pm SEM ( $n=3$ per time point). REL = Relative Expression Level. D. Sertoli cells were stimulated with FSH for one hour in the presence of actinomycin D and ${ }^{35} \mathrm{~S}$-Met/ ${ }^{35} \mathrm{~S}$-Cys, or were left untreated. Cell lysates were incubated with anti-PTEN antibody or with a pre-immune rabbit serum (PI). Here is shown a representative autoradiogram out of 3 independent experiments. The fold-stimulation versus control is indicated beneath the autoradiogram. n.s. $=$ non specific band. Shared superscripts indicate no significant difference, while different superscripts indicate significant differences, at the $\mathrm{P}<0.05$ level.

Figure 4: FSH signaling launches a proteasome-mediated proteolysis step to enhance PTEN protein level. A. Differentiating Sertoli cells were incubated with the MG132 proteasome inhibitor $(10 \mu \mathrm{M})$ for 2 hours prior stimulation with FSH for the indicated 
period of time. Representative Western blot of a time-course of FSH-induced PTEN expression in the presence of MG132. B. Quantification of the normalized PTEN signal obtained in the presence of MG132 ( $\mathrm{n}=3$ independent experiments). Results are expressed as the \% of the maximum PTEN induction +/- SEM. C. Control Western blot hybridized with an anti-phospho-IKB $\alpha$ to monitor MG132 efficiency, in Sertoli cells stimulated for 10 min with TNF $\alpha$. D. Differentiating Sertoli cells were incubated with the lactacystin proteasome inhibitors $(10 \mu \mathrm{M})$ for 2 hours prior stimulation with FSH for the indicated period of time. Representative Western blot of a time-course of FSHinduced PTEN expression in the presence of lactacystin ( $\mathrm{n}=2$ independent experiments). A vinculin probe was used to monitor gel loading. Shared superscripts indicate no significant difference, while different superscripts indicate significant differences, at the $\mathrm{P}<0.05$ level.

Figure 5: PTEN depletion restores FSH-dependent proliferation of Sertoli cells from prepubertal rats. A. Cells were transfected with the E2F1-luciferase reporter plasmid, and either the empty pBK-CMV plasmid or the pBK-CMV plasmid encoding antisense PTEN, as indicated. After 48 hours of expression, cells were stimulated with FSH for 8 hours before lysis. Results are expressed as relative light units +/- SEM normalized for transfection efficiency. Here are pooled the data from two experiments each done in sexplicates. B. Representative Western blot of proliferating Sertoli cells from neonate rats stimulated by FSH for 60 min. The membrane was hybridized with an anti-PTEN antibody, then reprobed with an actin probe to monitor gel loading. Shared superscripts indicate no significant difference, while different superscripts indicate significant differences, at the $\mathrm{P}<0.05$ level. 


\section{Figure 1}

A

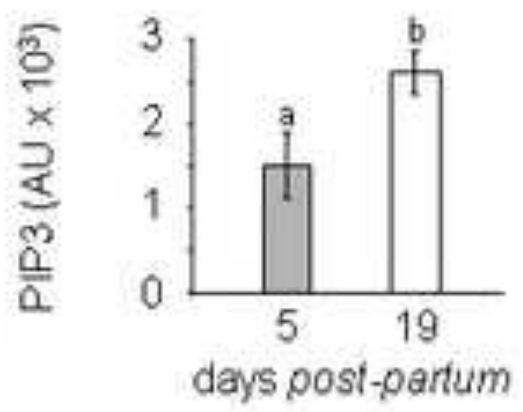

B

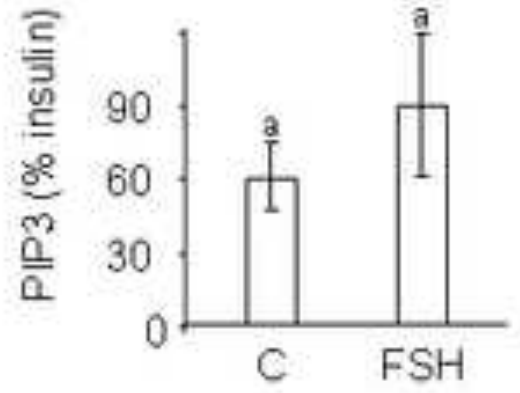

C

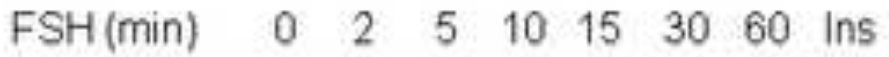

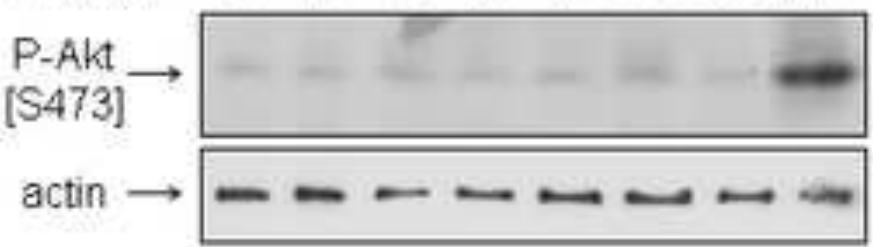




\section{Figure 2}

A

$\mathrm{FSH}$ (min) $\quad 0 \quad 2 \quad 5 \quad 10 \quad 15 \quad 30 \quad 60120240120$

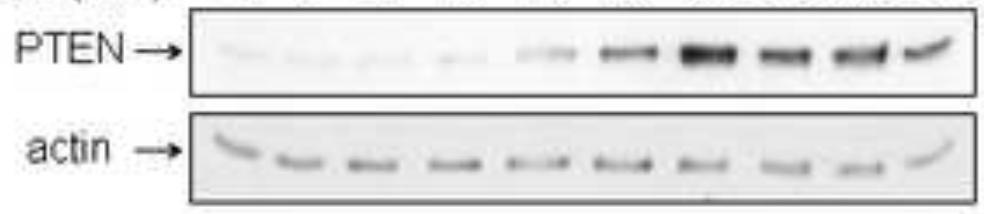

B

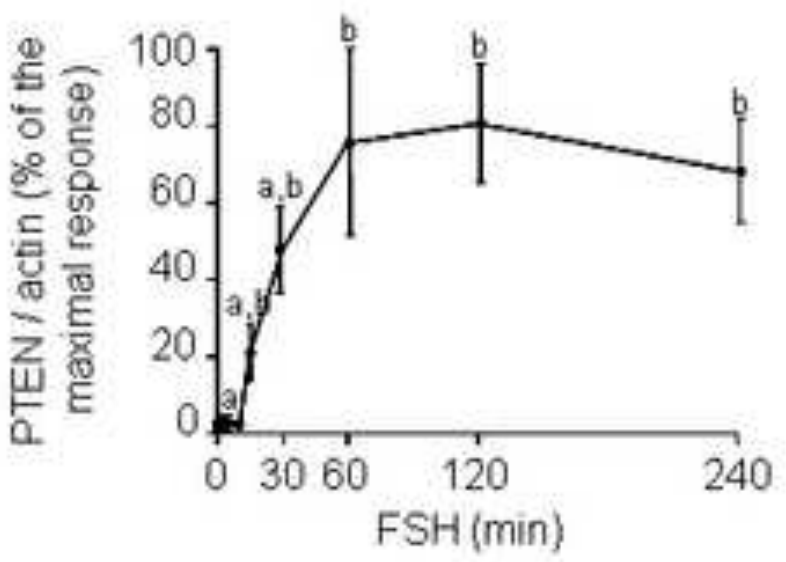

C

D

E
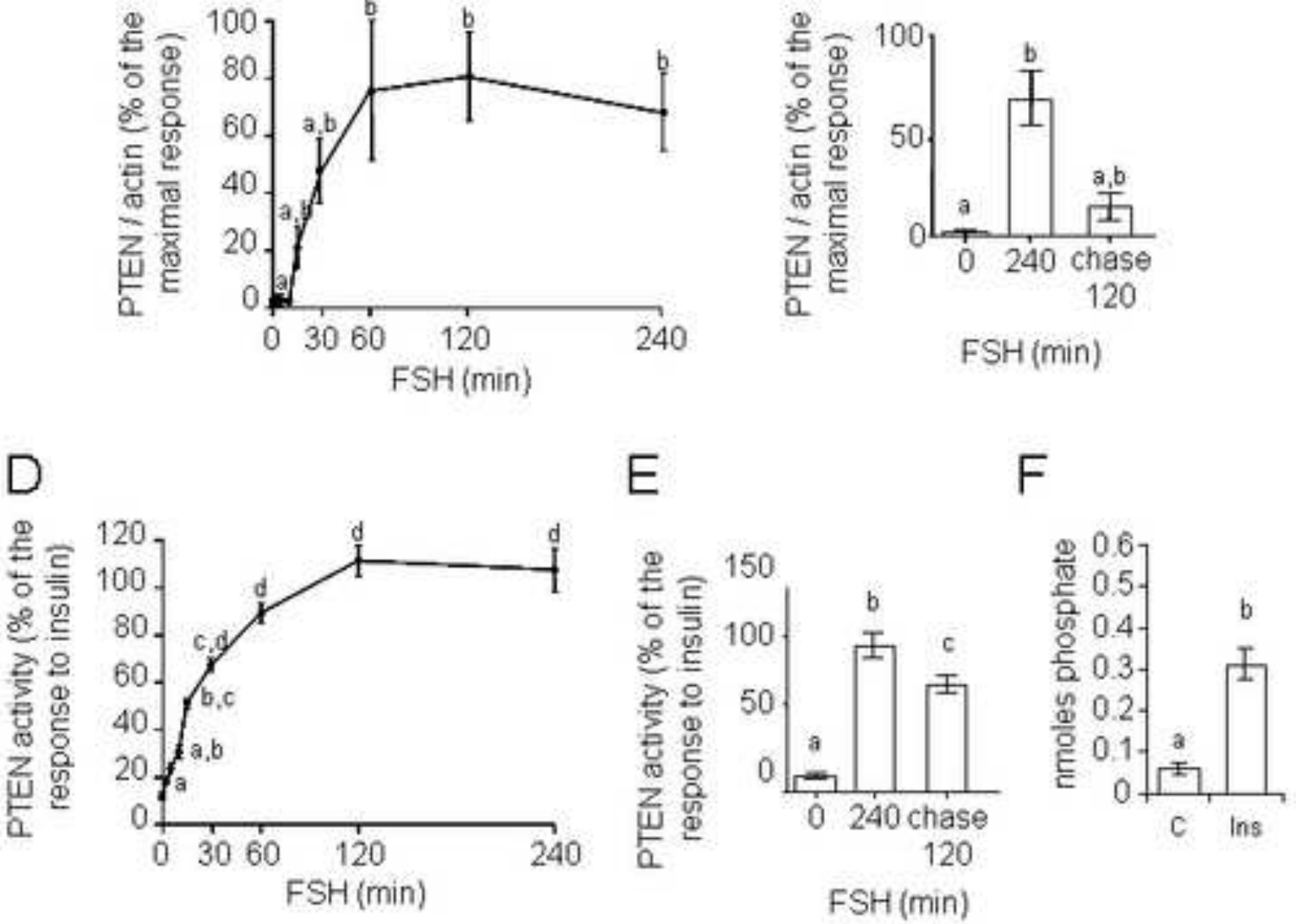


\section{Figure 3}

A

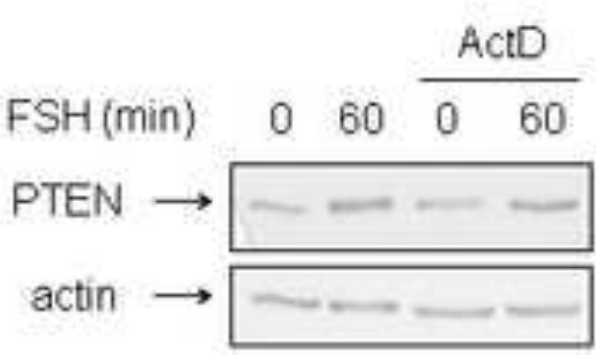

C

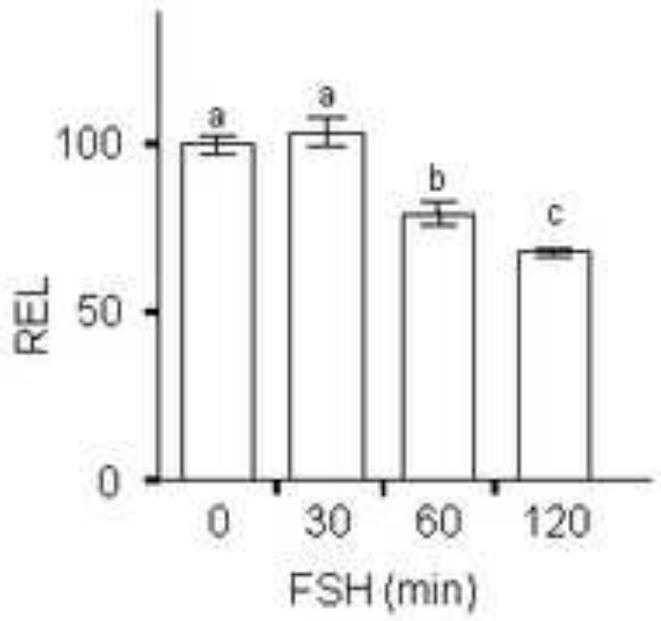

B

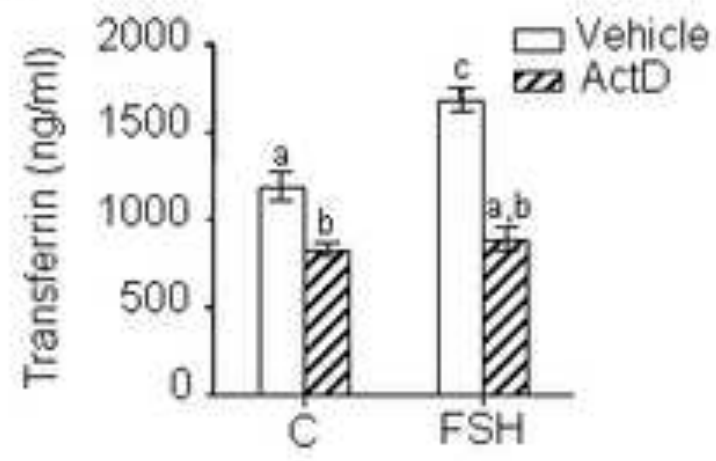

D

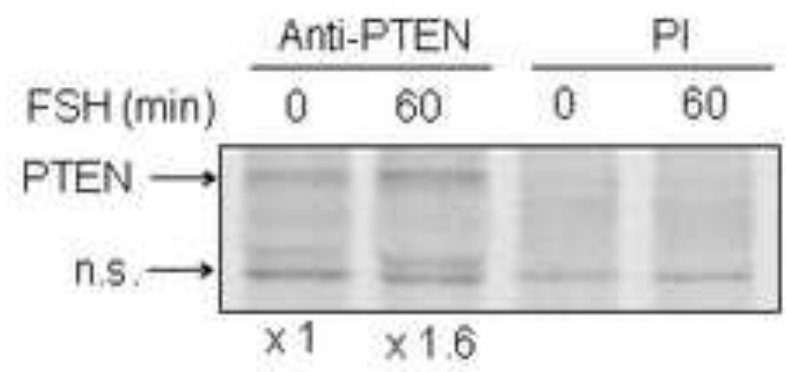




\section{Figure 4}

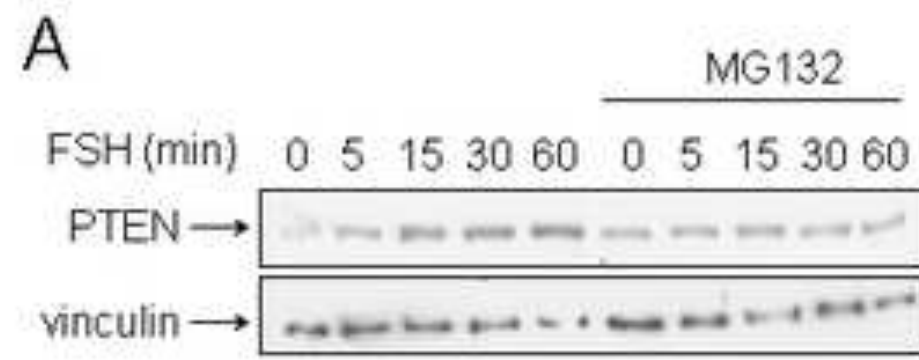

B
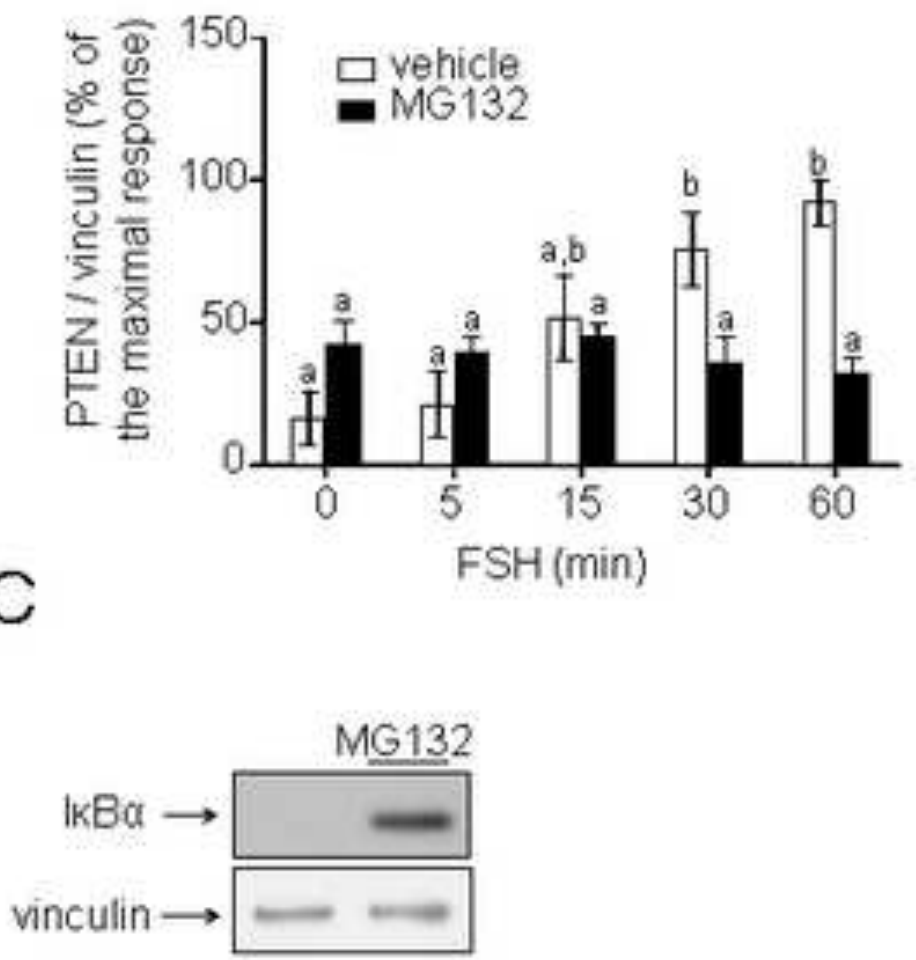

D lactacystin

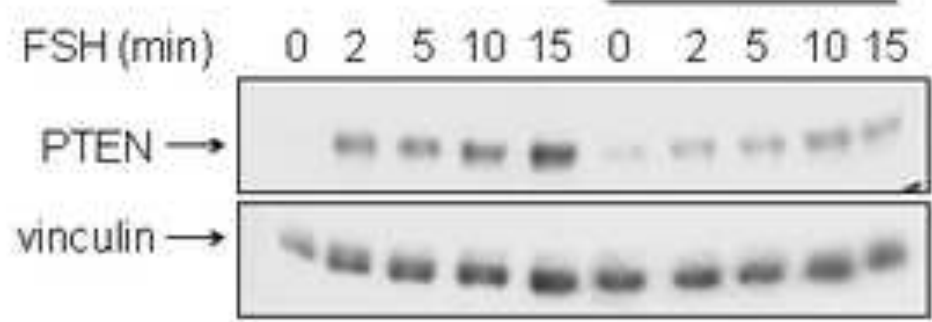




\section{Figure 5}

A

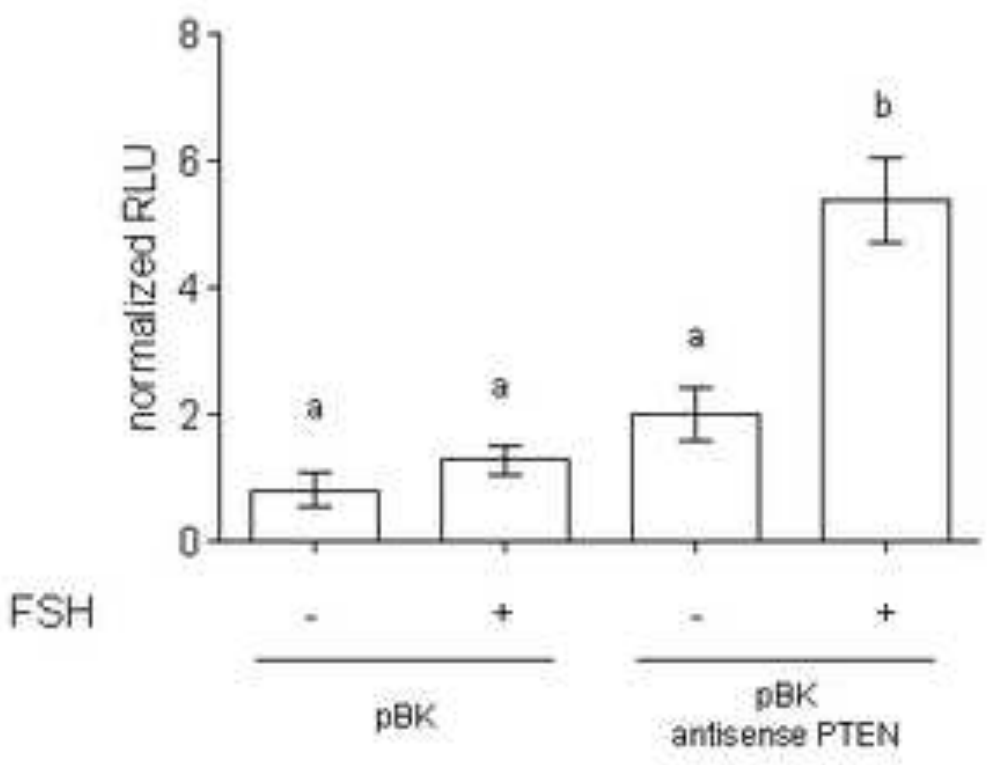

B

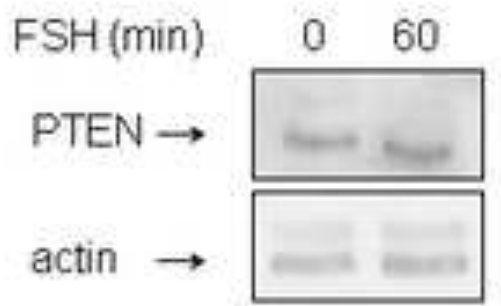

